\title{
AKUNTANSI PERNIKAHAN DI PULAU LOMBOK
}

\author{
Ali Fikri \\ Nina Karina Karim \\ Widyastuti
}

\begin{abstract}
The objective of this study is to analyze marriage from the accounting perspective. This study examined whether a husband (wife) was recognized as revenues, expenses, assets, or liabilities. Using a sample of 20 people as respondents on Lombok island community who have experienced divorces, the study conclude that marriage is regarded as expense and liabilities, instead of income or assets.
\end{abstract}

Keywords: marriage, assets, revenues, expenses, liabilities.

\section{Pendahuluan}

\subsection{Pengantar}

Ditilik dari sisi filasafat, ilmu pengetahuan diturunkan melalui proses pemberian Cahaya ketuhanan yang sering kita temukan dalam penjelasan berbagai Al-Kitab (Taurat, Inil, Quran), maupun sumber-sumber tulisan agama lainnya ${ }^{1}$. Perintah Ketuhanan yang diturunkan melalui Al-Kitab berupa anjuran dan larangan yang menimbulkan pahala dan dosa serta penebusannya (baik jangka waktu pendek dan panjang). Perjalanan waktu pengetahuan memecah dirinya melalui proses yang disebut dengan logika pemikiran. Pengembangan logika pemikiran didasari proses panca indra, terutama berasal dari proses melihat, membutuhkan waktu dan pemikiran panjang dan membentuk sebuah fungsi untuk memermudah kehidupan².

Bukti dari pengetahuan mengikuti alur pemikiran sifat ketuhanan dapat ditelusuri melalui proses pembuktian empiris yang mendukung pernyatan Tuhan yang tertuang dalam Al-Kitab. Hasil pembuktian melalui proses rasionalisasi pemikiran ini tidak semuanya serta merta memberikan dukungan, dan sebagian yang menolak. Namun, faktanya secara empiris semua pengetahuan selalu diawali oleh landasan filsafat dengan pemikiran yang selalu sama dengan puisi-puisi Tuhan.

IImu Akuntansi sendiri merupakan turunan pengetahuan yang didasari oleh Ruh ketuhanan ${ }^{3}$. IImu Akuntansi dimulai dari proses penciptaan entitas. Penciptaan entitas memiliki konsekuensi pemilik dan pengelola ${ }^{4}$. Pemilik/principal dan agen/pengelola kemudian memunculkan sisi Debit dan Kredit, pemilik asset dan pengelola aset. Pemilik hutang dan ekuitas merupakan pemilik entitas memberikan tugas kepada pengelola (manajemen) untuk mengelola aset dengan mengharapkan kontribusi atas operasionalisasi asset untuk menambah ekuitasnya ${ }^{5}$ (kekayaannya). Hasil dari operasionalisasi aset yang berupa laba selanjutnya harus dikembalikan lagi kepada pemilik modal dan hutang.

\footnotetext{
${ }^{1}$ Lihat Nasr, Sayyed Hossein (1997); Pengetahuan dan Kesucian. Pustaka Pelajar. Yogyakarta.

2 Proses ini dapat kita lihat dari perkembangan pengetahuan yang dimulai dari penemuan alat transportasi menggunaakan binatang, uap hingga bahan bakar.

${ }^{3}$ Istilah Ruh yang dimaksudkan daalam tulisan ini adalah Jiwa yang pemberi semangat,

${ }^{4}$ Lihat Jensen dan Meckling. (1976)

${ }^{5}$ Lihat Neraca Akuntansi.
} 
Operasionalisasi ini melalui serangkaian proses berupa pendapatan dan beban ${ }^{6}$. Pendapatan dan beban memilih jalan accrual untuk proses pembentukannya. Proses ini melahirkan turunan laba yang juga bersifat accrual $^{7}$. Accrual sendiri disinyalir memiliki beragam kelemahan dan memermudah perekayasaan pencatatan yang kurang memadai, namun hal ini berujung pada ambiguitas pembaca dalam memahami akuntansi. Permasalahan ini memang dapat saja diatasi melalui proses penyajian catatan atas laporan keuangan yang memadai, namun masih tetap sulit dipahami oleh pembaca yang tidak memahami konsep akuntansi.

Seluruh konsep filsafat ini berlaku pada seluruh jenis pengetahuan ${ }^{8}$, baik sosial dan non sosial ${ }^{9}$, yakniproses pengetahuan merupakan satu jalan pembuktian mengenai apa yang dinyatakan Tuhan merupakan sebuah kebenaran ${ }^{10}$. Kebenaran ini tersembunyi ke dalam berbagai bentuk yang semakin luas cakupannya dan menginspirasi manusia untuk terus berupaya menggali pengetahuan ${ }^{11}$, sebagaimana dinyatakan oleh seorang filosof:

"ketika manusia memecahkan teka teki sebuah atom, ia segeraa menemukan atom itu memunculkan teka-teki baru mengenai matahari di dalamnya"

Teka teki memecah pengetahuan menjadi lebih detail atau spesifik. Dimulai dari ranah ilmu sosial mengarah ke kejiawaan (tidak tampak), hingga ke arah ilmu non sosial mengarah ke tubuh (tampak) ${ }^{12}$. Memunculkan cabang cabang pengetahuan baru seperti psikologi, kedokteran, teknik, pertanian, peternakan, ekonomi dan lainnya, hingga pengetahuan tertinggi mengenai hukum. Akuntansi sebagai ranah pengetahuan pada akhirnya menyesuaikan dirinya dalam kehidupan sehari-hari melalui metode pencatatan (pencatatan aktiva, hutang, modal, pendapatan, dan beban) sebagaimana dinyatakan oleh Swardjono (2006) akuntansi sangat bergantung dari pertimbangan filosofi negara, sosial, politik, dan kemasyarakatan.

Dikaji dari kejadian sosial di masyarakat, fenomana menarik saat ini pada masyarakat maju adalah banyak terjadinya kasus kawin cerai yang terjadi, bukan hanya di negara maju, tetapi kejadian ini juga berlaku di masyarakat berkembang, Indonesia. Khususnya di pulau Lombok, kejadian kawin cerai yang terjadi di masyarakat telah terjadi sejak lama. Masyarakat Lombok beranggapan kawin cerai merupakan sesuatu yang sangat wajar, bahkan seringkali perceraian dilakukan melalui pemutusan kontrak melalui SMS (short message service) ${ }^{13}$. Dikaitkan dengan akuntansi, fenomena yang dilakukan oleh masyarakat ini dapat ditinjau dari pendekatan pencatatan

\footnotetext{
${ }^{6}$ Lihat konsep laporan Laba Rugi Akuntansi.

${ }^{7}$ Akrual berasal dari bahasa Inggris accrued yang memiliki pengertian mengakui. Pendaapatan dapat diakui jika berbentuk kas dan piutang, dan beban dapat diakui jika berbentuk kas dan hutang

${ }^{8}$ Filsafat dianalogikan sebagai pantai tempat pengetahuan bersandar dan tersebar ke berbagai tempat di daratan.

9 Proses pengetahuan ilmu eksak atau non-social dimulai dari konsep pengukuran yang berusaha untuk mengukur segala sesuatu (bersifat matematis) untuk lebih memermudah perhitungaan. Contoh yang paling jelas aadalah ukuran panjang yang dapat berupa kilometer, mil, yard dan seterusnya. Sebenarnya kesemua memiliki konsep pemikiran yang berbeda sehingga menghasilkan jenis dan ukuran berbeda namun berusaha unruk diseragamkan.

10 Konsep filsafat ketuhanan juga dapat kita temui dalam bidang fisika dan kedokteran mengenai teori ketidakseimbangan atom dan radikal bebas yang menyebabkan banyak permasalahan penyakit.

${ }^{11}$ Proses penelitian selalu menyatakan kekurangan yang dialami dan memiliki saran atau rekomendasi untuk memmerbaiki proses kekurangan yang dialami bagi penelitian selanjutnya.

${ }^{12}$ Pengetahuan mengenai kejiwaan (psikologi) dan kedokteran (tubuh)

${ }^{13}$ Kejadian seperti ini sering kali dilakukan oleh masyaarakat karena tekanan ekonomi, misalnya kasus TKI di luar negeri.
} 
neraca atau rugi laba. Pendekatan neraca akan mengakui perolehan suami atau istri sebagai aset dalam neraca, secangkan pendekatan laba rugi mengakui perolehan suami atau istri sebagai beban.

\subsection{Permasalahan Penelitian}

Telah menjadi sebuah kebiasaan jika masayarakat di Pulau Lombok mengaggap tradisi kawin cerai merupakan sesuatu yang sangat wajar. Pendekatan neraca mengakui perolehan suami atau istri sebagai aset dalam neraca, sedangkan pendekatan laba rugi mengakui perolehan suami atau istri sebagai beban Dikaitkan dengan akuntansi, penelitian ingin mengetahui pendekatan apakah yang diambil oleh palaku/masayarakat di pulau Lombok terkait dengan fenomena kawin cerai?

\subsection{Tujuan penelitian}

Mengetahui konsep akutansi yang diterapkan oleh masayarakat Lombok dalam pengakuan status pernikahan mereka.

\subsection{Manfaat penelitian}

Penelitian ini memiliki bebberapa manfaat, secara teoritis penelitian bertujuan untuk memahami teori akuntansi di masyarakat Lombok, secara praktis penelitian bertujuan untuk mnegetahui aplikasi akuntansi di masyarakat Lombok, dan secara kebijakan diharapkan dapat digunakan untuk pengabil kebijakan dalam nenentukan kebijakanakuntansi sosial di masyarakat.

\section{Beragam Ranah Pemikiran}

Menurut Husserl, persoalan dunia kehidupan bukan sebagai persoalan parsial, melainkan lebih sebagai persoalan universal dalam filsafat.Dari pendapat itu dapat diketahui masalah dunia kehidupan (lebenswelt) adalah dasar pemikiran manusia dalam mengembangkan ilmu pengetahuan yang diciptakannya. Husserl juga berpendapat setiap subjek transendental mengonstitusikan (menciptakan) dunianya sendiri-sendiri, menurut perspektifnya sendiri yang unik dan khas. Dunia itu tentunya bukan dunia objektif dalam pengertian dunia materi, melainkan dunia sebagaimana dihayati oleh subjek sebagai suatu pribadi ${ }^{14}$.

Keseharian perjalanan hidupnya, manusia sering mempertanyakan berbagai arti atau makna di dalam subjek yang dilihatnya baik secara indrawi dan budi (intelektif). Daya indrawi menghubungkan manusia dengan hal-hal konkret materiil ciri objek yang dapat ditangkap oleh indra, sedangkan pengetahuan akal budi (intelektif) merupakan suatu kesatuan dengan pengetahuan yang diperoleh lewat pancaindra. Oleh karena itu, pengetahuan indrawi dan intelektif ini tidak terpisahkan dan bersifat sinergis sehingga dapat dikatakan, pengetahuan indrawi telah terlibat proses intelektual yang memberikan pengertian dan pemahaman menurut akal budi ${ }^{15}$.

Rasa ingin mengetahui sesuatu hal dari manusia sangat besar terutama bagi yang berjiwa kritis. Keadaan ini akan berlanjut sesuai dengan perkembangan daya intelektual individu. Ketika manusia menerima jawaban dari berbagai pertanyaan yang diajukan, mereka merasakan

${ }^{14}$ (Muleong, 2004, pp.9)

${ }^{15}$ (Siregar, 2005; pp.1). 
kepuasan di dalam hatinya. Masalah kepuasan inilah yang sering dicari manusia untuk memperoleh kebahagiaan.Pertanyaan pertanyaaan dalam pemikiran keseharian kita seperti ke mana tujuan hidup kita? apa yang sebenarnya yang akan dicapai?, dan bagaimana cara mencapainya? pada akhirnya memberikan dasar pemikiran atau filsafat. Salah satu bentuk filsafat yang sering dipraktikkan berhubungan dengan filsafat hedonisme dan eudemonisme ${ }^{16}$.

Filsafat hedonisme sebenarnya telah ditemukan oleh Aristippos (sekitar 433-355 S.M.). Aristippos menyatakan 'yang sungguh baik bagi manusia adalah kesenangan'. Hal itu terbukti karena sudah sejak masa kecilnya manusia merasa tertarik akan kesenangan dan bila telah tercapai ia tidak mencari sesuatu yang lain lagi. Sebaliknya, manusia selalu menjauhkan diri dari ketidaksenangan. Akan tetapi, ada batas untuk mencari kesenangan dan perlunya pengendalian diri. Pengendalian diri ini tidak sama dengan meninggalkan kesenangan. Yang penting ialah mempergunakan kesenangan dengan baik dan tidak membiarkan diri terbawa olehnya, tapi menguasainya menurut kehendak kita. Manusia harus membatasi diri pada kesenangan yang diperoleh dengan mudah dan tidak perlu mengusahakan kesenangan dengan susah payah serta bekerja keras.

Filsuf Yunani lain yang melanjutkan hedonisme adalah Epikuros (341270 S.M.). Epikuros pun melihat kesenangan (hedone)sebagai tujuan kehidupan manusia. Menurut kodratnya setiap manusia mencari kesenangan, tapi pengertiannya tentang kesenangan lebih luas daripada pandangan Aristippos. Epikuros mengakui adanya kesenangan yang melebihi tahap badani. Ia menyatakan "yang dimaksud kesenangan adalah bukan kesenangan inderawi, tapi kebebasan dari nyeri dalam tubuh kita dan kebebasan dari keresahan dalam jiwa"dankesenangan rohani itu hanyalah bentuk yang diperhalus dari kesenangan badani, sehingga ia juga tidak membatasi kesenangan pada kesenangan aktual saja.

Meskipun pada dasarnya setiap kesenangan bisa dinilai baik, itu tidak berarti bahwa setiap kesenangan harus dimanfaatkan juga. Epikuros manjelaskan tiga macam keinginan, yaitu keinginan alamiah pokok (seperti makanan), keinginan alamiah tidak pokok (seperti makanan yang enak), dan keinginan sia-sia (seperti kekayaan). Hanya keinginan macam pertama harus dipuaskan dan pemuasannya dengan cara akan terbatas menghasilkan kesenangan paling besar, seperti dinyatakan Epikorus:

"Orang bijaksana akan berusaha sedapat mungkin hidup terlepas dari keinginan, sehingga dapat mencapai ataraxia"17.

Ataraxia ini berperan bagi jiwa, seperti kesehatan bagi tubuh. Orang bijaksana yang memperoleh ketenangan jiwa ini akan berhasil mengusir segala macam ketakutan (untuk kematian, dewa-dewa dan suratan nasib), menjauhkan diri dari kehidupan politik, dan menikmati pergaulan dengan sahabat-sahabat.

Pandangan lain yang hampir sama dengan pandangan hedonisme adalah pandangan eudemonisme. Pandangan ini berasal dari filsuf Yunani, Aristoteles (384-322 S.M.) yang menegaskan bahwa dalam setiap kegiatannya manusia mengejar suatu tujuan dan bisa dikatakan juga dalam setiap perbuatan manusia ingin mencapai sesuatu yang baik bagi dirinya.

\footnotetext{
${ }^{16}$ (Bertens, 2007).

${ }^{17}$ Ataraxia diartikan sebagai ketenangan jiwa atau keadaan jiwa yang seimbang yang tidak membiarkan diri terganggu oleh hal-hal yang lain. Ataraxia begitu penting bagi Epikuros, sehingga ia menyebutnya juga tujuan kehidupan manusia (Lihat Bertens, 2007, pp. 237).
} 
Menurut Aristoteles, semua orang akan menyetujui bahwa tujuan tertinggi dan makna terakhir hidup manusia adalah kebahagiaan (eudaimonia). Tapi jika semua orang menyepakati kebahagiaan sebagai tujuan terakhir hidup manusia, itu belum memecahkan semua kesulitan karena dengan kebahagiaan mereka mengerti banyak hal yang berbedabeda. Ada yang mengatakan bahwa kesenangan adalah kebahagiaan, ada yang berpendapat bahwa materi adalah kebahagiaan, dan ada pula yang menganggap status sosial atau nama baik sebagai kebahagiaan.

Aristoteles beranggapan bahwa semua hal itu tidak bisa diterima sebagai tujuan terakhir. Menurut Aristoteles, seseorang dapat mencapai tujuan terakhir (kebahagiaan) dengan menjalankan fungsinya dengan baik kegiatan secara rasional. Manusia tidak cukup melakukan fungsinya beberapa kali saja, tapi harus sebagai suatu sikap tetap. Hal itu berarti bahwa kegiatankegiatan rasional itu harus dijalankan dengan disertai keutamaan ${ }^{18}$. Individu kemudian menempuh berbagai upaya untuk mencapai kebahagiaan berdasarkan sudut pandang masing-masing, yaitu melalui pandangan neoklasik dan deontologi sebagai turunan dari hedonisme dan eudonisme yang dipraktikkan dengan cara berbeda ${ }^{19}$.

Paradigma neoklasik adalah paradigma utilitarian, rasionalis, memandang individu-individu berusaha memaksimumkan utilitas, dansecara rasional memilih cara terbaik untuk mencapai tujuan mereka ${ }^{20}$. Individu adalah unit yang mengambil keputusan, artinya, individu memberikan keputusan mereka sendiri. Berkumpulnya individu-individu dalam masyarakat dikatakan akan menciptakan efisiensi dan kesejahteraan maksimum dan dipandang sebagai keputusan rasional individual.

Menurut asumsi neoklasik, individu berusaha memaksimumkan satu utilitas (apakah berupa kesenangan, konsumsi, atau sekadar pendapat formal tentang tujuan bersama) secara rasional dan nilai serta emosi tidak boleh mengganggu pertimbangan rasional untuk mencapai tujuan. Konsep utilitas dalam pandangan neoklasik ini berorientasikan diri secara sempit dan hedonistik, yaitu semua tindakan ditujukan untuk memperoleh kesenangan

\footnotetext{
${ }^{18}$ Bagi Aristoteles ada dua macam keutamaan, yaitu keutamaan intelektual dan keutamaan moral. Keutamaan intelektual menyempurnakan langsung rasio itu sendiri, sedangkan dengan keutamaan moral rasio menjalankan pilihan yang perlu diadakan dalam hidup sehari-hari. Keutamaan seperti keberanian dan kemurahan hati merupakan pilihan yang dilaksanakan oleh rasio. Dalam hal ini rasio menentukan jalan tengah antara dua ekstrem yang berlawanan. Atau dengan kata lain, keutamaan adalah keseimbangan antara kurang dan terlalu banyak. Keutamaan yang menentukan jalan tengah itu oleh Aristoteles disebut phronesis (kebijaksanaan praktis). Phronesis menentukan apa yang bisa dianggap sebagai berkeutamaan dalam suatu situasi konkret. Karena itu, keutamaan ini merupakan inti seluruh kehidupan moral. Menurut Aristoteles, manusia adalah baik dalam arti moral jika selalu mengadakan pilihanpilihan rasional yang tepat dalam perbuatan-perbuatan moralnya dan mencapai keunggulan dalam penalaran intelektual. Orang seperti itu adalah bahagia. Kebahagiaan itu akan disertai kesenangan juga walaupun kesenangan tidak merupakan inti yang sebenarnya dari kebahagiaan.

19 Ide pemikiran bahwa paradigma neoklasik dan deontologi sebagai turunan dari filsafat hedonisme dan eudoneisme diturunkan berdasarkan pemikiran dalam kehidupan selalu terdapat dua hal dalam diri individu, yaitu individu yang mementingkan diri sendiri (neoklasik) dan individu yang mementingkan kepentingan bersama (deontologi).

${ }^{20}$ Lihat Etzioni (1992, pp.1). Menurut kodratnya tingkah laku manusia terarah pada kebahagiaan, maka suatu perbuatan dapat dinilai baik atau buruk, sejauh dapat meningkatkan atau mengurangi kebahagiaan sebanyak mungkin orang (Bertens, 2007; pp.247) atau tindakan yang tepat adalah tindakan yang memberikan konsekuensi terbaik atau kontribusi paling besar (Riahi dan Belkaoui, 2007; pp.91). Pandangan ini terutama banyak diterapkan di Barat yang muncul selama abad ke-17 ketika kosmos telah tersekularisasi karena peran agama yang melemah (Nasr, 2005; pp.84).
} 
atau menghindari penderitaan atau dengan kata lain individu berusaha menyejahterakan diri mereka.

Konsep utilitas ini berasal dari filsafat utilitarian yang berasumsi semua sarana yang digunakan serta tujuan yang diinginkan harus dapat memberikan utilitas maksimal. Para pendukung utilitarian, misalnya memberikan pendapat pada kesenangan, yaitu kesenangan itu 'baik' dan penderitaan itu 'jahat', yang menekankan bahwa penderitaan dan kesenangan tidak hanya kita harus ikuti, tetapi juga pembimbing etis kita. Kebahagiaan merupakan satusatunya utilitas yang harus dimaksimumkan baik dalam arti moral karena Tuhan bertujuan memberi kebahagiaan pada ciptaanNya.

Ketika dihadapkan pada asumsi bahwa konsep kesenangan tentang utilitas itu amoral, asosial, dan banyak bertentangan dengan perilaku manusia, kaum neoklasik menunjukkan konsep tentang utilitas yang pada hakikatnya sangat berbeda, tetapi diberi nama yang sama, yang berisi pelayanan kepada orang lain dan komitmen kepada nilai-nilai moral, di luar kesenangan pribadi. Analogi secara konseptualnya, yaitu konsumsi oleh orang lain dijadikan sumber kesenangan diri. Jika seseorang bertindak secara altruistik, kesenangan orang yang diperoleh dari tindakannya telah menjadi sumber kesenangan pelakunya, yaitu bagian dari utilitasnya. Asumsi ini kadang-kadang menganggap individu-individu mementingkan diri sendiri secara sempit dan tidak memiliki motif-motif altruistik sama sekali. Tindakan-tindakan altruistik dianggap sebagai penyebab upaya untuk meningkatkan reputasi, memperoleh persetujuan sosial, dan sebagainya. Misalnya, ketika Thomas Hobbes ditanya 'mengapa ia memberi kepada pengemis, dan apakah hal itu karena ajaran Kristiani?', ia menjawab 'aku berbuat demikian karena satu tujuan, yaitu untuk membebaskan diri dari kesengsaraan karena melihat pengemis itu' (Losco, 1986 sebagaimana dikutip Lihat Etzioni, 1992, pp. 54).

Meskipun demikian, konsep tentang utilitas yang telah dibicarakan di atas jika dilihat dari sisi etika dianggap masih kurang dan memiliki metodologi tidak sempurna meskipun konsep utilitas tersebut benar bagi versi utilitarianisme. Tindakan altruistik (atau tindakan sukarela) merupakan tindakan untuk meningkatkan kesenangan atau utilitas pelakunamuntindakan pengorbanan, misalnya tidak sesuai dengan konsep ini. Jika kita berasumsi mencari kesenangan dan menghindari penderitaan memotivasi individu, harus disimpulkan orang-orang suci menikmati pengorbanan mereka; dan menyimpulkan orang-orang suci tentu orang yang suka menderita. Namun, bila kita melepaskan diri paradigma utilitarian, kita akan melihat banyak individu memang sengaja melakukan sesuatu karena mereka menilainya sebagai kewajiban (Etzioni, 1992; pp.27). Sistem etika yang mengukur baik buruknya perbuatan bukan berdasarkan hasil, melainkan semata-mata berdasarkan maksud dan kewajiban disebut sebagai deontologi ${ }^{21}$.

Paradigma deontologis berasumsi bahwa perbedaan-perbedaan di antara individu-individu merupakan bawaan yang melekat pada struktur dan sangat memengaruhi hubungan. Asumsi-asumsi yangberbeda secara fundamental ini dalam konteks sosial disebut sebagai 'paradigma aku dan kita' yang berasumsi individu bertindak di dalam konteks sosial dan konteks ini tidak dapat dijadikan tindakan individu (Etzioni, 1992; pp.12).

\footnotetext{
${ }^{21}$ Pencetus gagasan sistem moral ini (deontologi) adalah filsuf Jerman, Immanuel Kant (1724-1804). Menurut Kant kehendak menjadi baik, jika bertindak karena kewajiban. Kalau perbuatan dilakukan dengan suatu maksud atau motif lain, perbuatan itu tidak bisa disebut baik. (Bertens, 1992; pp.254; Riahi dan Belkaoui, 2007; pp.92).
} 
Internalisasi dalam konteks sosial, yaitu lingkup parsialantara aku dan kita, merupakan perbedaan yang esensial di antara paradigma neoklasik dan paradigma deontologis. Paradigma neoklasik tidak mengakui adanya kolektivitas sama sekali, atau memandangnya sebagai agregat individu, dan sebagai bagian eksternal bagi individu. Individu dipandang terlepas dari komunitas dan dari nilai-nilai yang dimiliki bersama, dengan memperhitungkan apakah menjadi anggota atau tidak, memperhatikan nilainilai yang didiktekan atau tidak. Sebaliknya, paradigma deontologi berasumsi individu sekurang-kurangnya mempunyai suatuketerlibatan yang berarti dalam komunitas, kesadaran akan identitas bersama, dan komitmen kepada nilai-nilai, kesadaran bahwa kita adalah anggota yang satu atau yang lain.

Berdasarkan pandangan deontologi, terdapat ketegangan dan pencarian terus menerus keseimbangan di antara dua kekuatan, yaitu kekuatan komunitas dan kekuatan individu sebagai anggotanya. Jika kita memandang komunitas hanya sebagai suatu kesatuan individu yang untuk sementara bergabung demi kenyamanannya, berarti kita meninggalkan kebutuhan akan komitmen untuk melayani kebutuhan bersama dan untuk terlibat di dalam komunitas. Namun, jika kita melihat komunitas sebagai sumber autoritas dan legitimasi, berusaha atas nama kewajiban untuk melaksanakan standar-standar perilaku pada kelompok dan pada kita sendiri, ini berarti membiarkan dasar yang tidak cukup bagi kebebasan individu dan hak-hak individu yang lain.

Dari sintesis ini dihasilkan tarik menarik yang tak dapat dihindari yang seimbang di antara kedua unsur dasar komunitas. Individu-individu bisa menarik untuk mengecilkan komunitas dan komunitas memiliki kekuatan untuk menarik menggabungkan individu-individu. Kedua unsur itu tidak ada yang memperoleh kekuasaan namun saling mengoreksi dan menopang yang lain sehingga tercipta komunitas yang seimbang. Individu dan komunitas ini saling membentuk dan saling membutuhkan. Masyarakat bukanlah 'paksaan', bahkan juga bukan 'peluang'; ia adalah kita sehingga 'aku memerlukan kita agar bisa menjadi satu', seperti dinyatakan oleh Schopen Hauer $^{22}$ :

“Manusia seperti landak yang kedinginan: Mereka membeku jika terlalu berjauhan, tetapi saling menusuk jika terlalu berdekatan".

Selanjutnya jika ditinjau dari sisi moral dan kesenangan, terdapat perbedaan cara pandang antara neoklasik dan deontologi. Menurut pandangan deontologi, sifat perintah tindakan moral itu tercermin pada orang-orang yang bertindak secara moral, merasa bahwa mereka harus berperilaku dengan cara yang ditetapkan, mereka sebenarnya diharuskan karena terikat oleh kewajiban. Kita mengetahui bahwa hendaknya melakukan sesuatu karena hal itu benar, berbeda dengan melakukannya karena hal itu menyenangkan. Gagasan tentang perintah itu didukung oleh pengamatan bahwa orang mengesampingkan nilai tertentu karena membandingkan pertimbangan moral dengan yang lain. Prinsip-prinsip moral ini menjelaskan mengapa kenyataan bahwa orang kadang-kadang menghitung berapa yang akan diberikan atau jika mereka memberikan sesuatu, apa akibatnya terhadap reputasi mereka, dan sebagainya.

Individu-individu yang bertindak sesuai dengan moral bisa menggeneralisasikanperilaku mereka dengan memberikan alasan suatu

\footnotetext{
${ }^{22}$ Lihat Etzioni (1992; pp.9)
} 
tindakan kepada orang lain dan kepada mereka sendiri dengan menunjuk kepada kaidah umum, kewajiban-kewajiban deontologis mereka. Ungkapan 'berbuatlah kepada orang lain seperti kita ingin orang lain berbuat kepada kita' adalah contoh baik tentang kaidah yang digeneralisasikan.

Simetri atau kesamaan dibutuhkan dalam arti harus ada kesediaan untuk sesuai dengan orang lain atau setara dalam kedudukan atau hak yang sama meskipun dari segi lain tampak seperti sistem moral yang memaksa dan digeneralisasikan sebagai moral sebagai komitmen,bukan hanya untuk memuaskan diri (utilitas) tapi juga untuk orang lain sehingga tindakan tersebut harus dimotivasi secara intrinsik, dan bukan sasaran analisis saranatujuan.

Tindakan moral sering menyangkut maksud dan proses, bukan hasil. Berbeda dengan kesenangan, yang merupakan masalah mencapai tujuan yang diinginkan, komitmen moral dapat diungkapkan dengan mengambil langkah-langkah yang tepat (memilih arah yang disucikan secara moral) meskipun hasil yang dicari itu tidak diperoleh. Sebagai contoh, kita dapat mengikuti komitmen moral bila kita memberikan kesaksian di pengadilan untuk kepentingan pihak yang diperlakukan tidak adil bahkan meskipun orang itu dikalahkan, atau jika kita menyumbangkan darah kepada anggota keluarga yang ternyata akhirnya meninggal juga. Sejauh tindakan moral itu menyangkut konsekuensi, bagaimana konsekuensi itu diperoleh merupakan hal yang berarti. Singkatnya, kesenangan adalah masalah konsekuensi, dan tindakan moral di pihak lain adalah masalah maksud, masalah proses, dan konsekuensi.

Bila kita merenungkan hakikat istilah perilaku moral dan jenis tindakantindakan yang dicakup oleh istilah itu, kita menemukan alasan untuk mempertahankannya, yaitu 'tindakan moral adalah sumber nilai selain kesenangan'. Misalnya, menebus dosa, menghindari seks sebelum menikah, dan berpuasa kebanyakan dianggap bukan sebagai sebuah sumber kesenangan, dan memang, perilaku moral sering memerlukan pengendalian dorongan hati, penangguhan kepuasan, atau usaha yang kuat; banyak kesenangan yang netral secara moral atau yang dilarang dalam keadaan tertentu. Format yang khas dari banyak ajaran moral adalah 'engkau dilarang....', seperti dalam kebanyakan firman Tuhan di berbegai kitab suci agama serta hukum moral lainnya, dan menuntut tindakan tegas, seperti mengurus orang tua atau anak-anak terbelakang, menuntut upaya yang mungkin tidak akan dilakukan orang kecuali jika tindakan itu ditetapkan oleh moral.

Kesenangan dan perbuatan menurut komitmen moral tidak selalu atau harus bertentangan, tetapi kedua-duanya sering bersaingan dalam hal tuntutan atas sumber daya (waktu, energi, dan aset yang diperuntukkan bagi yang satu sering juga dituntut oleh yang lain), misalnya melaksanakan Ibadah haji merupakan suatu dorongan batin yang memberikan ketenteraman jiwa bagi pelaksananya meskipun harus dibayar mahal bagai kebanyakan individu.

Atribut penting yang membedakan komitmen moral dengan kesenangaan adalah bahwa nilai-nilai itu diinternalisasi ${ }^{23}$, artinya, individuindividu melihat nilai-nilai ini sebagai milik mereka, bukan sebagai kondisikondisi eksternal tempat mereka sekadar menyesuaikan diri. Setelah

\footnotetext{
${ }^{23}$ Internalisasi didefinisikan sebagai bagian dari proses sosialisasi seseorang belajar untuk mengikuti kaidah-kaidah dalam situasi-situasi yang membangkitkan dorongan untuk melanggar dan yang tidak memilikipengawasan dan sanksi (Lihat Etzioni, 1992, pp. 48).
} 
internalisasi ituterjadi, individu-individu mengikuti apa yang dianggap mereka garis moral perilaku meskipun tidak ada sanksi eksternal24.

Konsep tentang internalisasi moral itu menandai perbedaan utama antara neoklasik dan deontologis. Pada hakikatnya psikologi neoklasik menolak terjadinya internalisasi jenis apa pun, moral atau bukan. Mereka sangat didorong oleh lingkungan: (1) Mereka melihat orang sebagai menanggapi situasi mereka (individu-individu akan berperilaku sejauh perilaku moral itu diharapkan, yakni diganjar oleh persetujuan sosial) dan (2) mereka memperhitungkan masalah-masalah ini dan menanganinya dengan cara yang objektif, tanpa pertimbangan nilai atau belitan emosi.

Sebaliknya, deontologis menganggap mungkin ada dua jenis perilaku, yaitu orang bisa berbuat menurut apa yang berguna atau mengikuti kesadaran jiwa atas komitmen. Yang terpenting, mereka akan berperilaku berbeda bergantung pada apakah pilihan mereka itu didorong oleh pertimbangan moralitas sebagai paksaan eksternal atau mereka dibimbing oleh nilai-nilai batin mereka sendiri. Jadi, perilaku seseorang yang merasa bahwa "ia hendaknya bekerja keras" berbeda dari yang merasa bahwa "bekerja keras ada imbalannya". Hal itu mencerminkan kekuatan komitmen moral dan individu mempertahankan apa yang dilakukannya karena kesadaran kuat bahwa hal itu perbuatan yang benar meskipun, kebanyakan, bukan yang menyenangkan.

Dikaitkan pendekatan neokalsik dan deontologi di atas dengan kejadian sosial di masyarakat saat ini, seluruh kegiatan masyarakat diukur menggunakan konsep moneter, yaitu nilai mata uang. Status sosial kemasyarakatan ditinjau dari jumlah kapitalisasi aktiva yang dimiliki. Kejadian ini merembet pada ranah sosial yang lain, yaitu status perkawinan. Perkawinan yang selama ini dianggap sakral telah berubah mengikuti susut kepentingan. Sebagaimana telah dijelasakan sepintas pada bab sebelumnya, fenomana yang menarik pada masyarakat maju saat ini adalah banyak terjadinya kasus kawin cerai yang terjadi, bukan hanya di negara maju, tetapi kejadian ini juga berlaku di masyarakat berkembang, Indonesia. Dikaitkan dengan akuntansi, fenomena diakomodir akuntansi melalui metode pencatatan, yang mana akuntansi dapat mengakui perolehan sebuah aset menggunakan dalam neraca atau pendekatan laba rugi. Semua konsep ini sangat bergantung dari sisi pemikiran penyusun laporan keuangan. Logika pemikiran bergantung dari konsep/prinsip yang dianut individu, yang mana indipidu dipengaruhi oleh struktur masayarakat, dan terakhir pemikiran sosial masayarakat dipengaruhi oleh kondisi ekonomi dan politik.

Pulau Lombok terkenal sebagai Pulau Seribu Masjid, lantaran di pulau ini setiap desa bahkan dusun terdapat masjid. Pulau Lombok juga cukup terkenal dengan keindahan alamnya. Permasalahan yang kerap menimpa perempuan Lombok adalah terjadinya kawin cerai, fenomena ini lahir sebagai reaksi atas buruknya wajah pendidikan dan rapuhnya sendi-sendi perekonomian. Kemiskinan yang menimpa masyarakat mendorong terjadinya perkawinan usia dini. Begitu perempuan di sini menginjak akil baliq, orang tua segera mencarikan jodoh, yakni laki-laki yang akan menikahi anaknya. Menjumpai perempuan muda dengan usia 15 tahun menggendong anak, bukanlah pemandangan asing di pulau Lombok. Orang tua berharap, dengan segera

\footnotetext{
${ }^{24}$ Contoh kekuatan nilai-nilai yang terinternalisasi, misalnya meskipun perceraian telah disahkan dalam masyarakat Amerika pada tahun 1960-an dan 1970-an, survei informal menunjukkan sedikit orang yang meninggalkan istri atau suaminya yang menderita sakit berkepanjangan dan tidak dapat disembuhkan seperti penyakit kanker, lumpuh setelah serangan otak, dan semua penyakit yang sangat membebani.
} 
menikahkan anak gadisnya, beban ekonomi keluarga akan berkurang. Beban beralih pada suami perempuan itu.

Kenyataanya tidaklah demikian, di saat musim panen tiba, lamaran datang membanjiri setiap rumah orang tua yang memiliki anak gadis. Begitu musim paceklik melanda, perempuan muda yang telah dinikahi itu bagai daun berguguran, diceraikan oleh laki-laki yang telah menikahinya. Menyandang status janda di usia muda bukanlah perkara sepele. Apalagi jika perkawinan sebelumnya telah dikaruniai anak, lengkaplah beban dan derita yang ditanggung kaum perempuan. Kaum prempuan, janda muda beranak, harus menanggung beban untuk menghidupi anak-anaknya seorang diri.

Kaum laki-laki akan pergi begitu saja. Perempuan tidak bisa menuntut apa-apa. Hanya bisa pasrah. Apalagi perkawinan dilakukan jarang ada yang tercatat di Pengadilan Agama. Kaum perempuan di pulau kami begitu gampang dinikahi dan begitu gampang pula diceraikan. Laki-laki begitu gampang mencari perempuan lain untuk menikah lagi. Di tengah keputusasaan kaum perempuan yang telah diceraikan. Ketika ada tawaran kerja ke luar negeri untuk menjadi TKW (Tenaga Kerja Wanita), maka kaum wanita di pulau Lombok berbondong-bondong mendaftarkan diri. Sebagai TKI ${ }^{25}$. Kaum laki-laki sebagai penentu kebijakan selanjutnya memutuskan bagaimana menetapkan pencatatan akuntansinya.

\section{Metode Penelitian}

\subsection{Lokasi dan Responden Penelitian}

Berdasarkan tujuan penelitian, yaitu untuk memahami kondisi masyarakat dihubungkan dengan fenomena kawin cerai dan perlakuan akuntansi atas kegiatan tersebut di Pulau Lombok; penelitian akan difokuskan pada masyarat (pria dan wanita) yang telah melalui tahap tersebut, yang berlokasi di Kota Mataram, Lombok Barat, Lombok Utara, Lombok Tengah, dan Lombok Timur. Responden akhir sejumlah 20 orang masyarakat yang telah mengalami perceraian, ataupun bercerai dan kemudian menikah kembali.

\subsection{Metode Pengumpulan Data}

Hampir sama dengan metode riset lainnya, metoda fenomenologi juga menggunakan serangkaian proses dan teknik untuk melakukan penggalaian data di lapangan. Kebanyakan teknik ini juga digunakan juga dalam metode riset lainnya, terutama dalam metode riset kualitatif. Penelitian ini menggunakan metode pengumpulan data pengamatan berperan dengan cara terlibat mengikuti orang-orang yang diteliti dalam kehidupan sehari-hari, melihat apa yang mereka lakukan, kapan, dengan siapa, dan dalam keadaan apa, dan menanyai mereka mengenai tindakan mereka. Kehadiran peneliti untuk berinteraksi dengan subjek diharapkan memberi pemahaman lebih utuh penelitian melalui wawancara menggunakan alat perekam, catatan, dan teknik observasi sebagai partisipan untuk melihat secara langsung perilaku yang berhubungan dengan fenomena yang diamati (Sanders, 1982, Saerang, $2001,87)$. Hasil wawancara antara organisasi pengelola dan masyarakat serta

\footnotetext{
${ }^{25}$ Provinsi NTB menyumbang pengiriman TKI terbesar nomor dua setelah Jawa Timur. Dari total sekitar 60.000 TKI resmi yang diberangkatkan dari NTB, $80 \%$ berasal dari Pulau Lombok. Angka ini belum dihitung TKI ilegal yang jumlahnya diperkirakan 3 kali lipat dari TKI legal. Dan kaum perempuan di pulau kami kebanyakan diberangkatkan untuk menjadi pembantu rumah tangga (PRT) ke negara-negara Timur Tengah.
} 
analisis dokumen juga digunakan sebagai bahan pembanding untuk memperjelas hasil penelitian.

Penggalian data di lapangan peneliti lakukan dengan cara mengamati sekaligus melakukan wawancara dengan responden, yaitu masyarakat yang telah melalui proses perceraian. Informasi yang diperlukan dalam penelitian, yaitu penafsiran pemahaman informan mengenai sudut pandang tentang pernikahan dan ekonomi (yang dikaitkand engan akuntansi). Mengikuti Sanders (1982), langkah awal peneliti melakukan intentional analysis denganmengubungkan antara obyek yang dipersepsikan (noema) dan pemahaman subjekif (noesis) pada obyek penelitian melalui catatan dan laporan-laporan, individu yang bekerja pada organisasi, aktivitas organisasi, dan persepsi masyarakat mengenai akuntabilitas.

\section{Hasil Penelitian}

\subsection{Pengantar}

Pulau Lombok adalah sebuah pulau di kepulauan Sunda Kecil atau Nusa Tenggara yang terpisahkan oleh Selat Lombok dari Bali di sebelat barat dan Selat Alas di sebelah timur dari Sumbawa. Pulau Lombok memiliki penjang kurang lebih $70 \mathrm{~km}$ dengan luas mencapai $5.435 \mathrm{~km}^{2}$, dengan jumlah penduduk pada tahun 2001: 2.722.123 jiwa.Daerah selatan pulau ini sebagian besar terdiri atas tanah subur yang dimanfaatkan untuk pertanian, komoditas yang biasanya ditanam di daerah ini antara lain jagung, padi, kopi, tembakau dan kapas.

Kasus perceraian di Pulau Lombok masih menjadi banyak topik pemeritaan di media masa, seperti koran lokal Lombok Pos yang menulis Tingkat kasus perceraian di Lombok Barat (Lobar) dan Lombok Utara masih tinggi; Di Kabupaten Lombok Tengan dalam sehari, 15 orang mengajukan gugatan cerai; hingga Seribu Masjid, Seribu Janda.

Informasi yang diperoleh dari media sosial menyaakan Berdasarkan data dari Pengadilan Agama (PA) Giri Menang Lombok Barat mengungkapkan, tercatat sehari menerima 40 perkara permohonan perceraian, dan Meski tidak semua gugatan dikabulkan..Sementara jumlah perkara yang masuk di PA Giri Menang hingga saat ini sebanyak 1500. Gugatan tersebut untuk perkara cerai, waris, poligami dan lainnya. Sepanjang tahun 2016 PA Giri Menang dari Januari hingga Oktober sudah menceraikan 417 orang. Penggugat didominasi oleh perempuan dengan alasan pemicu percerian beragam, seperti pernikahan yang belum matang (pernkahan dini), kesenjangan pendapatan suami, tanggung jawab, sudah tidak cocok, hingga perselingkuhan.

Kabupaten Lombok Timur pun merupakan satu daerah di Nusa Tenggara Barat (NTB) tertinggi angka perceraiannya. Hingga bulan Oktober 2016 ini, PA Selong telah menerima 1.599 perkara gugatan yang sebagian besar didominasi kasus perceraian yakni sebanyak 884 kasus perceraian. Bahkan, Lombok Timur termasuk 5 besar tertinggi angka perceraian di Indonesia setelah Indramayu yang menempati posisi pertama. Bahkan, Lombok Timur sempat bertengger diperingkat 3 secara nasional. Masyarakat di Lombok Timur cenderung lebih memilih bercerai dengan pasangannya hanya karena alasan klasik yakni meninggalkan pasangannya untuk menikah lagi. Aasan perceraian dari pasangannya karena tidak pernah diberikan nafkah lahir bathin selama 2 tahun berturut-turut. (lebih sering menimpa Tenaga Kerja Indonesia (TKI) yang bekerja di luar negeri), dan sebagian besar gugatan cerai yang juga diajukan adalah dari istri (cerai gugat) yakni mencapai 719 
kasus, sedangkan, dari suami (cerai thalak) sekitar 165 kasus.

Fenomena tersebut sebagian besar merupakan kasus permsalahan ekonomi, dan dipandang dari sudut akuntansi menjadi sebuah kajian tersendiri. Kajian yang dimaksud dalam penelitian ini difokuskan pada kajian filosofis akuntansi sehubungan dengan teori akuntansi terkait proses perekayasaan laporan keuangan.

\subsection{Pengakuan Pernikahan; Pendapatan atau Beban???}

Secara Teori konsep harga perolelehan dimulai dari sebuah kesepakatan bersama untuk mengakui adanya transaksi. Pengakuan tersebut mencerminkan sebuah kepentingan bersama yang secara sukarela mengakui bahwa kedua belah pihak memiliki kepentingan masing masing yang dijembatani melalui proses transaksi.

Proses pernikahan juga diawali oleh subuah kesepakatan melalui perjanjian (akad nikah) untuk secara bersama sama bertransaksi saling memberi dan melayani. Dalam konsep akuntansi proses pernikahan menggambarkan konsep pengakuan pendapatan. Pendapatanpun merupakan hasil dari upaya yang harus dikeluarkan terlebih dahulu. Pengeluaran yang dimaksud untuk memberikan tenaga, pikiran, waktu, dan sumber daya untuk menjalankan kegiatan operasi (pernikahan). Sebagai penjelas, konsep pernikahan berarti proses mengeluarkan beban dalam upaya memeroleh pendapatan (ketenangan jiwa dan keturunan). Pernyataan ini diungkapkan oleh sebagian besar pasangan suami istri (sebelum bercerai).

"Tujuan saya menikah untuk memeroleh anak yang baik sebagai penerus keturunan. Saya sangat berharap banyak dapat memeroleh pahala dari proses pernikahan" (Bapak 1).

"Menikah merupakan sebuah kewajiban kepada Tuhan" (Ibu 1).

"Cinta, tututan batin, tuntutan keluarga, Agama, dan masyarakan sebagai alasan utama saya menikah" (Bapak 2).

"Dahulu saya merasa sangat rugi untuk tidak menikah, karena saya sulit tidur..." (Bapak 3).

Semua pernyataan yang diungkapkan di atas merupakan ungkapan awal dari pasangan masing masing suami istri (pasutri) sebelum mereka menikah. Berharap pernikahan adalah sebuah pendapatan. Seiring perjalanan waktu, pernikahan pasangan mulai merasakan keindahan dan lelah keseharian. Proses ini menguji dan mengevaluasi masing masing indivdu mewakili berbagai kepentingan masing-masing. Perjalanan panjang membutuhkan sumber daya (beban) yang tidak sedikit, pemenuhan kebutuhan sehari hari. "awalnya, saya tidak merasa bahwa pernikahan itu sangat berat, untuk saling mengisi dan menerima..." (I bu 1 dan Bapak 2).

"banyak faktor yang harus kami pikirkan ketika menikah, mulai dari memahami kepentingan pribadi, kepentingan keluarga masing masing pihak, hingga tuntutan anak" (I bu 2).

"pernikahan tidak hanya membutuhkan cinta, namun juga materi. Cinta timbul jika materi dasar telah terpenuhi" (Bapak 3).

Pemenuhan pada akhirnya mengalami masa sulit yang menyebabkan mereka harus bercerai

"faktor ekonomi tidak dapat dipenuhi oleh pasangan kemi, mereka harus bekerja di luar meninggalkan rumah berhari hari; saya bingung dan terpaksa harus kembali ke rumah orang tua, meskipun tidak ada suami, saya harus berhutang ke sana ke mari ..." (I bu 3). 
"semakin lama suami semakin kasar... ; menurut saya wajar jika saya ingin kebutuhan pokok dipenuhi. Namun karena sulitnya pekerjaan dan suami tidak memiliki uang, seringkali ia pergi ke luar rumah dan jika diperingati selalu marah-marah. Tekanan batin saya sangat berat....; itu alasan saya bercerai. Jika tidak bisa dinasehati secara halus, saya bisa kok mencari nafkah sendiri" (I bu 4).

"sudah 4 tahun suami ke Malaysia, tidak pernah pulang menegok anak. Awalnya suami sering mengirimkan uang sebulan sekali, namun sudah beberapawaktu ia tidak mengirimkan uang lagi. Kabar terakhir yang saya dengar, ia sudah memiliki istri di Malaysia...; saya harus bilang apa lagi... saya tidak rela" ( I bu 5).

"awalnya saya sangat berharap banyak suami dapat memenuhi kebutuhan saya, namun saya salah sangka...." (I bu 6).

Pendapat lain juga dinyatakan oleh para suami mengenai pernikahan mereka. "cinta hanya awalnya saja...; usai itu pikiran saya berubah...." (Bapak 4).

"jika melihat anak orang, saya ingat anak di rumah; namun jika melihat istri orang, saya lupa istri di rumah.... akhirnya saya kawin lagi" (Bapak 5).

"perempuan banyak, saya bisa menikah sampai 4 kali lagi" (Bapak 6).

"istri saya dapat memenuhi nafkah anak dan dirinya...; mereka berjualan, jadi saya tidak terlalu berfikir untuk memberikan sesuatu kepadanya" (Bapak 7).

"fenomena kawin cerai di Lombok itu perihal biasa, banyak teman saya yang menikah lebih dari satu kali. Kami merasa gagah jika menikah lebih dari satu kali. Tidak terlalu saya pikirkan" (Bapak 8).

"istri jangan terlalu dimanja, kalau mereka banyak tuntutan, kita cari yang lain...." (Bapak 9).

Pernyataan tersebut dihubungkan dengan teori akuntansi memiliki konsekuensi pengakuan pendapatan dan beban. Secara akuntansi pendapatan diartikan sebagai arus masuk yang berasal dari kenaikan aset, sedangkan beban diartikan sebagai penurunan aset atau kenaikan hutang. Permasalahan di atas dapat dianalis pernikahan yang dilakukan selama ini merupakan beban hidup yang harus mereka tanggung, dan sebagian besar merasa sedikit manfaat yang diperoleh.

\subsection{Aset atau Kewajiban?}

"ada uang abang disayang, tiada uang abang ditendang...." (Bapak 4).

Menurut akuntansi aset diasumsikan sebagai sesuatu yang dapat mengahasilkan pendapatan, dan kewajiban merupakan sumber pendanaan untuk membiayai aset selain dari modal sendiri. Selama sesuatu dianggap sebagai hal yang dapat menghasilkan pendapatan di masa depan (memiliki potensi pendapatan di masa mendatang) maka selayaknya diakui sebagai aset meskipun belum ada hak untuk memiliki. Logika pemikirannya hutang digunakan membeli aset yang akan menghasilkan pendapatan untuk membayar melunasi kewajiban

Suami ataupun istri secara harfiah merupakan aset yang dicatat dalam neraca rumah tangga. Baik suami dan istri memiliki kesamaan kewajiban untuk menghaslkan pendapatan (berupa lahir dan batin). Fenomena keseharian penyebab perceraian karena tuntutan ekonomi. Kemiskinan menimbukan konfilk jasmani yang merambah ke rohani. Konflik menunculkan emosi yang berujung pada putusnya tali pernikahan. 
"selalu yang dituntut kewajiban, hak kami disepelekan..." (Ibu 7)

"saya harus bagaimana....?" (I bu 8)

"suami jarang memberi nafkah...."(I bu 9)

"suami lebih suka di luar...." (I bu 10)

"istri terlalu cerewet...; banyak tuntutan, ingin selalu diperhatikan" (Bapak 8)

"seandainya anak tidak mencari ibu kandungnya, saya upayakan mencari ibu baru..." (Bapak 9)

wajarlah pahala menikah besar, kewajiban yang ditanggung juga besar...

(Bapak 10)

Ungkapan di atas menggambarkan bertapa besar kewajiban yang mereka korbankan dalam rumah tangga. Anggapan suami (istri) sebagai aset hilang karena tuntutan ekonomi.Dikaitkan pendekatan neokalsik dan deontologi di atas dengan kejadian sosial di masyarakat saat ini, seluruh kegiatan masyarakat diukur menggunakan konsep moneter, yaitu nilai mata uang. Status sosial kemasyarakatan ditinjau dari jumlah kapitalisasi aktiva yang dimiliki. Kejadian ini merembet pada ranah sosial yang lain, yaitu status perkawinan. Perkawinan yang selama ini dianggap sakral telah berubah mengikuti susut kepentingan, sebagaimana dikatakan oleh seorang penyair: "ketika kemiskinan mengetuk dan masuk melalui pintu, cinta lari melalui jendela..."

\section{Simpulan, Keterbatasan dan Saran, dan Kontribusi Penelitian}

Penelitian ini bertujuan untuk menganalisis pernikahan dilihat melalui perspektif akuntansi, apakah suami (istri) diakui sebagai pendapatan, beban, aset, kewajiban. Menggunakan sampel responden sebanyak 20 orang masyarakat di pulau Lombok dari pasangan yang telah mengalami perceraian di peroleh simpulan bahwa pernikahan dianggap sebagai sebuah beban dan kewajiban, bukan pendapatan atau aset.

Demikian, penelitian ini memiliki beberapa keterbatasan, diantaranya responden yang diambil umumnya kalangan ekonomi bawah yang mengalami kesulitan ekonomi, sehingga memang sangat rentan untuk bercerai; kasus kawin cerai yang dialami responden tidak menentu, ada yang hanya bercerai sebanyak 1 kali, 2 kali, dan 3 kali. Tidak menggunakan responden yang konsisten mengalami perceraian berkali-kali (misalnya di atas 3 kali) untuk lebih memertajam hasil analisis. Disarankan penelitian berikutnya dapat menggunakan responden dengan kalangan ekonomi menengah ke atas (mapan) untuk lebih memerjelas penyebab perceraian, dan jika memungkinkan menggunakan reponden yang telah menikah (bercerai) berkali kali.

Adapun kontribusi penelitian ini secara teoritis dapat digunakan untuk menambah pengetahuan mengenai fenomena kawin cerai dalam masayrakat di pulau Lombok; secara praktis dapat digunakan oleh pasangan suami istri agar mencegah perceraian; dan secara kebijakan dapat digunakan oleh pemerintah daerah dalam mengantisipasi kejadian kawin cerai.

\section{REFERENSI}

Astusti, Widia, 2015. Narasi Derita Perembuan di Pulau Lombok.http://jejakmantra. blogspot.co.id/2015/07/narasi-deritaperempuan-pulau-lombok.html 
Bertens, K. (2007). Etika. PT. Gramedia Pustaka Utama, Jakarta.

Burrell, G. and Morgan, G. (1994). Sociological Paradigm and Organisational Analysis. London: Heinemann.

Etzioni, Amitai. (1992), Dimensi Moral; Menuju Ilmu Ekonomi Baru. Edisi Terjemahan, Penerbit Remaja Rosdakarya Bandung.

Jensen, Michael C. and William H. Meckling. (1976), Teory of the Firm: Manajerial Behaviour, Agency Cost and Owenership Structure. Jurnal of Financial Economics. October, 1976, V.3 No.4, pp.305-360.

Keiso, Donald E, Jerry J. Weygandt, dan Terry D Warfielf (2002). Akuntansi Intermediate. Erlangga, Surabaya

Lombok Post, 2016.

Moleong, Lexy. J. 2004. Metodologi Penelitian Kualitatif. Penerbit PT. Remaja Rosda Karya, Bandung

Nasr, Sayyed Hossein (1997); Pengetahuan dan Kesucian. Pustaka Pelajar. Yogyakarta.

Siregar, G. Laksmi, (2005). Menyingkap Subjektivitas Fenomena. Universitas Indonesia - Press, Jakarta.

Riahi, Ahmed dan Belkaoui, 2007. Accounting Theory. Salemba Empat, Jakarta.

Riduwan, Ahmad (2009). Tafsir Sosial Laba Akuntansi Kajian Semiotika Dekonstruktif Berbasis Filsafat Jacques Derrida. Universitas Brawijaya, Malang.

Saerang, David Paul Elia (2001). Accountability and Accounting in a Religius Organization: an Interactive Ethnographic Study of the Pantecostal Chruch of Indonesia. Disertation University Wollonggong.

Sanders, Patricia (1982). Phenomenology: A New Way of Viewing Organizational Research. Academy of Management Review. Vol. 7 (3) pp 353-360.

Suriasumantri, Jujun S., (2005). Filasafat IImu; Sebuah Pengantar Populer. Pustaka Sinar Harapan, Jakarta. 